\title{
THEMATIC SHIFTS IN CONTEMPORARY VIETNAMESE AMERICAN NOVELS
}

\author{
Quan Manh Ha \\ The University of Montana
}

Asian American narratives generally have been discussed by literary critics within the context of U.S. history and politics vis-à-vis the social issues that challenge the specific ethnic groups that produce them. In the Introduction to Imagine Otherwise, Kandice Chuh maintains rather emphatically that more current theoretical trends in Asian American literary criticism tend to employ paradigms established by scholars of postcolonialism and transnationalism, and that Asian American literature and criticism should "remain a politicized tool for social justice" for the immigrant communities (Chuh 2003, 4). The Vietnamese Americans' historical and immigration experiences are different from those of the majority of other Asian American groups, and early Vietnamese American literature usually critiques U.S. intervention and foreign policy during the Vietnam War, and it also addresses the problems of social injustice in the homeland, Vietnam.

Since 2003, some new voices have emerged in Vietnamese American novels that tend to avoid the traditional war-related issues treated by their Vietnamese American literary forebears. For example, both Dao Strom's Grass Roof, Tin Roof and Bich Minh Nguyen's Short Girls emphasize themes of cultural assimilation, ethnic identity, and generational gaps, which concern second- or third-generation immigrants, for whom the Vietnam War and the Vietnamese homeland are a less immediate concern. Interestingly, Monique Truong's The Book of Salt deals even with issues of French colonialism and the Vietnamese diaspora of the colonial period, which occurred prior to the World War II era, but she focuses on themes that also remain central to the Vietnamese American experience of the later twentieth century. She chooses to set her impressive novel in the Paris of Gertrude Stein and other American expatriates of the post-World War I period, rather than in the contemporary United States. Therefore, the problems of separation from the homeland and alienation within the adopted country are presented for examination at considerable critical distance from the immediate experience of those same problems as they occur in post-Vietnam War America. Thus, the perspective has shifted in Truong's novel from war politics per se to multiculturalism, and even to diasporic issues, treating the broader consequences for Vietnamese immigrants throughout the twentieth century. 
In Politicizing Asian American Literature, Youngsuk Chae addresses recent trends in the works of contemporary Asian American authors who, like Truong, also choose not to engage themselves in political discourse directed specifically toward social change in today's United States:

[M]ost "popular" Asian American multicultural writings have not situated their narratives in specific socio-political and historical contexts. Rather, they tend to decontextualize political and economic circumstances and the structural inequality that racial minorities and immigrants have faced by focusing mainly in issues of cultural conflicts, generational gaps with their parent generation, or identity crisis. (Chae 2008, 4)

Chae observes that Asian Americans generally still face "social discrimination" and "structural inequality," and that, by not addressing these problems, popular Asian American narratives unconsciously imply an acceptance of a status quo that ignores racial conflicts and promotes the American mythic ideals of democracy for all and endless opportunities for those who work hard (Chae 2008, 4). Chae takes a radical view on these matters, and in her confrontational assessment, she suggests that many contemporary Asian American writers are attracted to current trends in multicultural literature because of the market's strong demand for ethnic narratives that treat cultural assimilation and acculturation, but with little or no mention of the embarrassing history of racism and discrimination against people of color in the United States (Chae 2008, 15). Thus, in some ways, recently published Vietnamese American works conform with trends followed in Asian American literature in general, but in other ways they maintain their ethnic and artistic uniqueness.

This article discusses three major recently published Vietnamese American novels, produced by popular presses, emphasizing their thematic treatment of characters and social issues. I argue that, by concentrating on the themes of inferiority and invisibility, these novels, in their particular way, accommodate the popular American audience's thirst for informative ethic literatures, on the one hand, but deal non-confrontationally, or only indirectly, with very serious conflicts and contradictions that Vietnamese American experienced in attempting to realize in realizing their American dream, on the other. These contemporary Vietnamese American works either exclude war-related topics or mention them only in passing, and their authors address American social issues only from a distance, and in a particularly Vietnamese American way. The Book of Salt is discussed first in the analyses that follow. 


\section{Monique Truong's The Book of $S_{A L T}$}

Truong's debut novel, The Book of Salt (2003), is a striking example of early twenty-first-century Vietnamese American literature, which avoids war-related topics while focusing on other issues of importance to Asian American authors, such as ethnicity and personal identity, race and racialization, gender politics and sexual identity. Her novel's intricate themes, innovative blends of historical fact with fictional possibility, and plausibility in extraordinary character development have gained an enthusiastic readership and made The Book of Salt a national bestseller. Understandably, Truong has won coveted awards for her creative originality and eloquent narrative style. The plot of Truong's novel is structured non-chronologically, intertwining the narrator-protagonist Binh's past in Vietnam with his present life in the GertrudeStein (Truong's spelling of the name) household in Paris. This stylistic device is not uncommon in postmodern fiction, in which the narrative voice often is that of a character who "may coax or ravish or prompt our outrage, compel us with its understated sincerity, seduce us with a dance of revelation and concealment" (Glausen 2003, 23). Nevertheless, Binh's flashbacks are integrated effectively into the forward flow of the novel's events, making The Book of Salt a unified work of complex stories-within-stories.

While many earlier Vietnamese American novels are semi-autobiographical, Truong takes a postmodern approach to writing historical fiction in The Book of Salt, which is related to that suggested by John Barth in his article "The Literature of Exhaustion," but not in complete imitation. In a conversation about her novel with the publisher, when asked how she was inspired to write a book about a Vietnamese cook who works for Gertrude Stein and Alice B. Tolkas in Paris, she replied that, when she was in college, she purchased The Alice B. Tolkas Cook Book because of her curiosity about Tolkas's marijuana brownie recipe. However, she soon realized that the book she bought was more like a memoir than a cookbook per se, and in the chapter entitled "Servants in France," she discovered that Tolkas describes two Indochinese men who were employed to cook for her and her partner at 27 rue de Fleurus: "One of these cooks responded to an ad placed by Tolkas in the newspaper that began 'Two Americans ladies wish - .' By this point in the book, I had already fallen for these two women and for their ability to create an idiosyncratic, idyllic life." Truong was "surprised and touched to see a Vietnamese presence" in the household and to discover his familial relationship with Stein and Tolkas. She then surmised that this live-in Vietnamese cook must have known much about the personal, domestic lives of these two American women: "[I]n the official history of the Lost Generation, the Paris of Gertrude Stein and Alice B. Tolkas, these 'IndoChinese' cooks were just a minor footnote. There could be a personal 
epic embedded in that footnote."1 Thus, the idea for her novel was born and began to grow.

Wenying Xu notes some parallels between the fictional Vietnamese cook Binh in The Book of Salt and two actual Indochinese cooks who worked for Gertrude Stein and her partner in Paris (Xu 2007, 128-29). In The Alice B. Tolkas Cook Book, for instance, we find Trac, a Vietnamese cook who responded to the cook-wanted newspaper advertisement and who "spoke French with a vocabulary of a couple dozen words" (Tolkas 1954, 186). This cook, as Tolkas remembers, often used negation in his conversation with his hostesses; he "would say, not a cherry, when he spoke of strawberry. A lobster was a small crawfish, and a pineapple was a pear not a pear" (Tolkas 1954,186). Truong borrows and incorporates these particular peculiarities into her portrayal of Binh in her novel, describing him as a little Indochinese man "who can't even speak proper French, who can't even say more than a simple sentence" (Truong 2003, 15-16). After Trac left the Stein household to establish his own family, Nguyen was hired. Prior to his arrival in France, Nguyen had been "a servant in the household of the French Governor-General of Indo-China, who brought him to France" (Tolkas 1954, 187). Similarly, Binh in The Book of Salt had worked in the kitchen of the French Governor-General in Saigon; however, the fictional Binh, unlike the historical Nguyen, was fired for his involvement in a homosexual affair with the French Chef Blériot before sailing to Paris for resettlement. Another parallel that $\mathrm{Xu}$ points out in her analysis of The Book of Salt is that, in reality, Gertrude Stein and Tolkas were arrogant and condescending, just as are the fictional GertrudeStein and Tolkas, who act superciliously toward their Vietnamese cook. In Truong's novel, they make mildly discriminating observations about Binh, their live-in Vietnamese cook, as well as Lattimore, an American southerner and occasional guest of mixed race who is "passing for white" in Paris (Truong 2003, 128-29).

Generally, inferiority is associated with invisibility and voicelessness. American media and popular culture always have feminized Asian men and portrayed them as subordinate and submissive in same-sex relationships and in sexual affairs generally. Richard Fung, in his article "Looking for My Penis," writes, "Whenever I mention the topic of Asian actors in American porn, the first question I am asked is whether the Asian is simply shown getting fucked" because "Asian and anus are conflated" (Fung 1996, 187). Similarly, in the Introduction to Racial Castration, David Eng also points out that the "antithesis of manhood" is assumed by the West about the East: "the Westerner monopolizes the part of the 'top'; the Asian is invariably assigned the role of the 'bot-

1 "The Book of Salt: A Reader's Guide" <http://www.houghtonmifflinbooks.com/read ers_guides/truong_salt.shtml> 
tom" " in gay narratives and pornography (Eng 2001, 1). Although many Asian American novelists try to deconstruct this Western assumption or perception of Asia and Asian people as feminine and meek, Truong does not. Interestingly, male masculinity in the early twentieth century was of ten associated with colonial rule, as Judith Halberstam observes, especially when it referred to British colonial power and Western European colonialism in Asia and Africa (Halberstam 2006, 99).

In Binh's relationships with non-Asian men (mostly Caucasian, but one significantly of "mixed blood"), he plays the passive role. His name, [Hoa] Binh, means peace in English, and peace, as interpreted by Milton $\mathrm{J}$. Bates, is a feminine concept while "[w]ar, aggression, and violence are masculine" (Bates 1996, 139). To cite one early example from the novel, Truong describes Chef Bleriot's masculine physical attributes: "[he] made up for his youthful appearance with a harshness of manner [. . .]. We would have called him Napoleon, except that he defied us by being neither too short nor pudgy around the waistline. No, Bleriot was as commanding in his looks as in his manners" (Truong 2003, 59). Physically, Bleriot is more masculine and aggressive than Binh, and when they make love, Bleriot is the dominant while Binh is the submissive partner: "Even in the throes of what I choose to remember as love, my body felt the lines stretched between us, razor-sharp when pressed against the flesh" (Truong 2003, 195).

Binh is cast in a mold of such sexual submission throughout the novel, just as his lowly employment as a cook places him in a position of service to many who find him useful, at least for a while. Binh certainly plays the subordinate role in his sexual relationship with Lattimore: Binh longs to feel Lattimore's skin, and he is rewarded with a kiss "until we are skin on skin" (Truong 2003, 109). Binh characterizes the nature of his relationship with Lattimore as follows: "I cook for him, and he feeds me" (Truong 2003, 213). Cooking is nurturing, which, like peace, is feminine, and the verb feeds in this context should be understood metaphorically-it implies that Lattimore is the dominant partner who actually employs Binh for the services he renders. Describing his cooking, Binh of ten uses sexual allusions and metaphors to explain how he prepares a dish. For example, when he was nine years old and learning how to cut scallions into little "O"s, he used a silver knife (which evokes a phallic image) and cut himself. The accident implies erotic connotations of penetration and bleeding: "my throat unclogs, and my body begins to understand that silver is threading my skin" (Truong 2003, 72).

Besides the theme of sexual identities, there is a colonial discourse between Binh and his non-Vietnamese employers and lovers, which illustrates the social and racial relationship between the inferior and the superior. As noted above, in Saigon, Binh worked as a kitchen boy, and 
his brother Anh Minh was the sous chef in the kitchen of the GovernorGeneral. However, Minh was not appointed chef de cuisine, because of his status as a Vietnamese national. He was chagrined at the arrival of the French Chef Bleriot, whom the Governor-General's wife, the Madame, invited from France to replace a former, aging chef. At first, Binh compares Chef Bleriot to a "typical colonial officer" who gave orders and established rules in the kitchen (Truong 2003, 132). Madame felt sympathy for her French chef after hearing her secretary talk about his sexual affair with Binh, but she felt angry at Binh for having humiliated Bleriot, who was merely a victim of Vietnamese lies and "alleged falsehood" (Truong 2003, 132). Although Madame did not discriminate against homosexuals, she did not approve of interracial relationships, because they challenged her colonialist belief in racial hierarchies: "She did not care about the relations of two men, just as long as they were of the same social standing and, of course, race" (Truong 2003, 132). Eventually, Binh was released from service because of his impertinent relationship, but Bleriot, although chastened, was allowed to maintain his position in the kitchen. This illustrates how Binh, one of the colonials, was humbled by the French colonialists who were occupying his country. In Race and Resistance, Viet Thanh Nguyen states that the queer body often is used to address colonialism and that sexuality provides metaphors for both colonizing and decolonizing (Nguyen 2002, 128). Bleriot exploited Binh sexually in order to satisfy his emotional needs and carnal desires, albeit with Binh's consent and active participation. Nevertheless, this relationship and its humiliating outcome, especially for Binh, suggest the detrimental consequences that are potential in a colonist's physical exploitation of the colonized's body.

Subsequently, living in Paris, Binh struggles with his identity as a homosexual and as an exile living within expatriate communities residing there. Although the Americans, within the context of the novel, were not colonizing Vietnam in the 1920s and 1930s, Binh is well aware of the power relationships between his Mesdames and himself, and of their condescendingly colonial attitude toward the Inchochinese. GertrudeStein and Tolkas maintain their regal superiority over Binh, and they treat him merely as a live-in cook, nothing more and nothing less. When Binh receives a letter from his brother Anh Minh, they admit to him that "they had never seen my full name in writing before" (Truong 2003, 5; emphasis added). Their statement implies that they had failed to perceive him to be a complete human being because one's name represents one's identity. GertrudeStein even expands his first name to "Thin Bin" because of his small physique, and she "merrily" mispronounces Binh to make the two words rhyme (Truong 2003, 32). In his Mesdames' eyes, he is a cook and a retainer whose background is not a subject of 
their interest or curiosity. Their only concern is "the fruits of exile, the bitter juices, and the heavy heart. They yearn for a taste of the pure, seasalt sadness of the outcast whom they have brought into their homes" (Truong 2003, 19). Therefore, they refer to him as a "Little Indochinese," a "Chinaman," a "foreigner," an "asiatique," or an "Indochinese laborer, generalized and indiscriminate, easily spotted and readily identifiable all the same" (Truong 2003, 142, 183, 152). Binh further says, "They would believe that their cooks have no bodily needs, secretions, not to mention excrement, but we all do. We are not clean and properly sterile from head to toe. We come into their homes with our skills and our bodies, the latter a host for all the vermin and parasites that we have encountered along the way" (Truong 2003, 64). When served, they are concerned about the food that is placed in front of them, and they generally ignore "the hands that prepared and served it" (Truong 2003, 65).

Ironically, his American employers perceive him as an invisible individual whose tongue cannot utter a fluent sentence in a foreign language; thus, in their minds he registers as "blind" and deaf to life (Truong 2003, 144). Binh, in fact, is reasonably sophisticated and expressively articulate in his internal monologues. He is able to control his tongue and produce eloquent sentences fraught with humor, irony, and rich nuances of meaning. In his monologues, he feels equal to his French employers in Saigon and ridicules them for their cultural arrogance and inability to "detect the defiance of those who serve them" (Truong 2003,14). He even assures himself that he is not the fool that GertrudeStein thinks he is because his "lack of speech" should not be equated with any "lack of thought" (Truong 2003, 153). He uses the word ignorance to describe GertrudeStein's perception of her live-in cook and his thoughts, because while she does not know much about his private thoughts and personal life, he knows much about hers and her partner's. It is he who cooks for them, creates the setting for their performance upon the stage of their lives, and gains personal power, although restrained, from his function as a domestic in their household. It is he who could determine the destinies of his employers because " $[\mathrm{t}]$ here is a fine line between a cook and a murderer, and that line is held steady by the men of my trade" (Truong 2003, 67). Metaphorically, Binh's attitude toward his Mesdames and his defiance of Bleriot's colonial arrogance demonstrate the patient strength of the Vietnamese people in Vietnamese history and their resistance to colonialism, both from Western and Eastern invaders.

\section{Dao Strom's Grass Roof, Tin Roof}

Another Vietnamese American novel published in 2003 is Dao Strom's Grass Roof, Tin Roof. Strom's novel can be divided into four 
parts. Part one is narrated by a third-person omniscient narrator. During the Vietnam War, Tran Anh Trinh, a female Vietnamese newspaper reporter, faced persecution for her politically reactionary, subversive writings and had to flee Vietnam with a son and a daughter just before the war ended. After a few years in a refugee camp, she and her children immigrated to the United States through the sponsorship of Hus Madsen, a Danish American, who later became her husband. Part two is recounted from a first-person point of view by April (also called Thuy), Tran's daughter. April's stories focus on her relationship with Tran and Hus, her childhood memories of Thien (her brother) and her later memories of Beth (her half-sister), her adolescence in America, and her socialization with non-Vietnamese friends. Part three is narrated from a third-person omniscient point of view; it describes Thien's life as a mechanic, his friendship with ethnic-American friends, and his sexual encounters with non-Vietnamese girlfriends. Part four comprises April's diary, which she writes during her first trip to visit relatives in Vietnam after her mother's death. This fourth and final section finds April fraught with bewilderment and confusion as she tries to understand her Vietnamese roots and the influence of American popular culture upon the developing Vietnam of the 1990s.

The author describes Tran's lifestyle, before the Vietnam War ended, as "eccentric" and "unorthodox" (Strom 2003, 31, 32). Tran refused to comply with ingrained traditional mores because they stifled her desire for freedom and gender equity. Whether Tran was an adherent of the international movement of feminism or simply a very strong female figure in her society, she actually did not appear feminine in the sense in which many other women sought to present themselves in Vietnam at the time. She debunks the Western assumption that Asian women are meek, submissive, and obedient within a patriarchal, male-dominated society. In Saigon, she became a well-known writer, and her reputation brought deference and respect from her colleagues, who regarded her as a "knowing" person, even when she was silent. At work, they "trusted, even feared her; for here was one woman who couldn't be and didn't need to be fooled or wooed," due to her acumen and perspicacity (Strom 2003, 23).

However, Tran's often masculine behavior and attitudes are abandoned in the United States through her decision to settle into married life with Hus, and she no longer assumes the posture of the "knowing" woman that she had tried so hard to project in Vietnam. In Maxine Hong Kingston's The Woman Warrior, Brave Orchid (the narrator's mother) attended medical school and was a doctor in China before coming to California. However, in the United States, her professional credentials are not acknowledged; she must run a laundry shop and live the life of a 
middle-class, working woman-remaining invisible in American, whitedominant culture (Kingston 1989, 57, 135). Tran's situation is similar to Brave Orchid's in the results of her transition from the Old World to the New World. Because of her displacement and alienation, Tran must adapt to a new environment, with help from Hus, himself an immigrant who has lived in the United States for more than twenty years.

In Vietnam, she had sought social deference and professional respect, but in the United States, she becomes "enamored of him [Hus] for his authority and confidence-his compassion!-and he will teach them [her and her children] many new things" (Strom 2003, 48). Thus, Strom offers a problematic representation of Asian women in U.S. culture. Mary Yu Danico and Franklin Ng point out that Asian women are considered "desirable mates to White men" because Asian women are "dutiful, obedient, and sexually accessible" (Danico and Ng, 2004, 122). Tran's marriage to Hus leads her to accept submission and voicelessness. This is partly due to language barriers, cultural differences, and a disorienting unawareness of limited social possibilities. Her tongue is deprived of the sharpness and acuteness it had possessed in Vietnam; she understands that she and her children are political refugees, "the dislocated," sponsored by a kind-hearted, sympathetic man, and she is no longer the well-known, popular writer who was respected and appreciated earlier by her Vietnamese readers (Strom 2003, 57).

Her new condition of voicelessness is revealed when, in Nevada, she encounters William Bentley, a belligerent neighbor who accuses Thien and her sister's Vietnamese husband of shooting his dog, and who demands that Hus pay him five-hundred dollars in compensation. Tran observes the obstreperous argument between Hus and William and feels helpless. When William ridiculed her, her face turned red, and "her gaze flinched beneath the man's mocking attention. Her mouth was fast becoming a thin, disappearing, injured little line" (Strom 2003, 66). This is the first time during her life in the United States that she witnesses racism and prejudice so blatantly hurled against Asian people. While Hus understands the situation, which results from William's "fear or rage or spite," his wife does not (Strom 2003, 72).

Maria P.P. Root, in her discussion of Asian American women and stereotypes, generally concurs with Danico's and Ng's observations about Asian women: "Asian or Asian American women are characterized as childlike, fragile, and innocent" in many American popular movies; therefore, white men, or white characters, are cast "in a paternalistic role as a justification" for their attraction to Asian women (Root 1998, 213). Tran's encounter with William demonstrates the characteristics noted by Root, and Hus acts as an experienced, fatherly protector in this situation. Hus's paternalistic role on this occasion parallels the role of the United 
States described by Senator John F. Kennedy in his luncheon remarks at a conference held in Washington, D.C., in 1956: "Vietnam represents a test of American responsibility and determination in Asia. If we are not the parents of little Vietnam, then surely we are the godparents. We presided at its birth, we gave assistance to its life, we have helped to shape its future." 2 Hus seems to reflect in his familial situation the protective role assumed by the United States in its political attitude toward Vietnam. Following this climatic incident, Strom does not develop Tran more extensively in the novel; a few years later, Tran is hospitalized for tuberculosis and then dies, in the middle of the novel.

Strom's earlier representation of the Vietnamese fathers of Tran's two children also is problematic for readers seeking normative values in her novel. Danico and $\mathrm{Ng}$ observe that the American media of ten portray Asian men as emotionless. To illustrate their point, Danico and $\mathrm{Ng}$ single out certain critical comments on the movie The Joy Luck Club (1993) that emphasize how this movie stereotypes its depiction of an "Asian American woman, married to a cold, heartless Asian American man, who [the heroine] later found happiness with a Caucasian man." Such cliché images and characters suggest that conjugal happiness is unobtainable with Asian American men and that "Caucasian men are the saviors, or [a] Prince Charming who comes to the rescue" (Danico and Ng 2004, 121, 127). In Strom's novel, both Thien's and April's fathers are indifferent about the results of their sexual affairs with Tran. They showed no emotion toward Tran when she gave birth to Thien and April, even denying their paternity. However, Hus, a Caucasian man, feels responsibility, compassion, and sympathy toward Tran after he reads her autobiographical stories, and he decides to sponsor her immigration to America. In this case, Hus, a Caucasian, indeed is represented as a "savior," while April's and Thien's Vietnamese fathers are the "cold and heartless" types to which Danico and Ng take exception.

Among major Vietnamese American novels published after 2000, Grass Roof, Tin Roof has not been widely appreciated. It is experimental in its form, and it has some flaws, which have prevented it from gaining popularity among the general reading public, and particularly among Asian American literary critics. For example, some of its major characters are not fully developed, such as Tran and Hus, and the author devotes many pages to describing April's and Thien's coming-of-age experiences, their entrance into adulthood, and their experimentations

2 John F. Kennedy, "Remarks of Senator John F. Kennedy at the Conference on Vietnam Luncheon in the Hotel Willard, Washington, D.C., June 1, 1956," John F. Kennedy Presidential Library \& Museum. Historical Resources. <http://www.jfklibrary.org/Historical+ Resources/Archives/Reference+Desk/Speeches/JFK/JFK+Pre-Pres/1956/002PRE PRES12SPEECHES_56JUN01.htm>. 
with sex. A resulting unevenness in structure sometimes makes the novel seem overly digressive. Despite these apparent shortcomings, the novel reflects some crucial themes of Asian American fiction: womanhood, mother-daughter relationships, racial and bi-cultural identity, personal and ethnic identity crises, cultural displacement, and the immigrant experience. Strom's novel, like others discussed in this article, takes the Vietnamese American novel in a new direction. Although the novel's reception indicates that her experiment is not totally successful, the novel is, nevertheless, significant because recent Vietnamese American fiction seeks to express the on-going experience of the Vietnamese American community, explaining the subtle, private recesses of life that more politically focused novels sometimes leave concealed. It is also significant because recent Vietnamese American authors such as Strom seek new modes of self-expression through experimentation with variation on traditional American literary genres.

\section{Bich Minh Nguyen's Short GirLS}

Two years after Bich Minh Nguyen published her first book, Stealing Buddha's Dinner (2007) — a memoir of her childhood that has been widely and well received by book reviewers and the reading public—she published her first novel, Short Girls-a domestic-realist story of two Vietnamese American sisters, Van and Linny, who grew up and developed extremely contrasting identities in the Mid-West. Compared to Truong's The Book of Salt and Strom's Grass Roof, Tin Roof, Nguyen's Short Girls employs a simple plot and straightforward character development. The novel is divided into sixteen chapters, entitled "Van" and "Linny," alternately, describing the life of each sister. The narrative is clear, despite flashbacks, and at times humorous. Short Girls is an intergenerational novel about contrasting personalities and lifestyles, the fragility of human relationships, dysfunctional communication, generational gaps within a family, and the collapse of the American dream.

A major theme of Short Girls is the individual's attempt to negotiate his or her cultural and ethnic identity as an immigrant and/or refugee in the United States. Each of the four family members in the Luong family — Dinh Luong (father), Thuy Luong (mother), Van and Linny (daughters and sisters) - finds his or her own way to negotiate cultural values in order to assimilate successfully into American mass culture, although their approaches contrast greatly. In Negotiating Identities, Helena Grice observes that Asian American women writers often focus on the "issues of space, place and the idea of 'home'" because places and spaces characterize "our meanings and associations" (Grice 2002, 199, 200). Mr. Luong's separation from his ancestral homeland, Vietnam, leads to his 
psychospacial ${ }^{3}$ perception of himself as "the Other" in the United States. He feels alienated and isolated because he, like most Vietnamese people, is short, compared to the majority of American men. He repeatedly reminds his daughters: "We live in this country with some of the tallest people. That's America" (Nguyen 2009, 59). Because of what he perceives as inferiority in physical height, he believes that it is important for the Vietnamese to manifest superiority by being "smarter" (Nguyen 2009, 61).

Mr. Luong denies the fact that he has become "naturalized," and he prefers to use the term "normalized" to describe his status after taking his oath of loyalty in front of the American flag (Nguyen 132). He argues that the word "citizenship" inscribed on a piece of paper does not make him a true American. The transformation will occur only after he ceases to be invisible in the society around him - after he gains stature and visibility through recognition of his talents and inventive accomplishments. He expresses these thoughts to Van: "You know what we are? No one. We have no citizenship. Refugees aren't belonging anywhere." To this, he adds, "In America, we don't belong until we make them see it [our intellectual equality]" (Nguyen 2009, 133). He does not demand recognition as exceptional within the society so much as acknowledgement by the society of his worthwhile existence within it.

Bishnupriya Ghost and Brinda Bose, in the Introduction to their book Interventions, coin the term configuration to describe "the act of shaping a personal collection of significations" by which a character's identity is constructed (Ghost and Bose 1997, xxii). This term is useful in distinguishing the two sisters, Linny and Van. It is indeed through decisions made by each sister in selecting the attitudes and deeds that define their individual lives that they become individuated by the author. Linny is influenced by American popular and consumer culture. She is unable to manage her finances effectively, and she spends her money on trendy garments, luxurious jewelry, and high-heel shoes, while she maintains a poorly kept apartment, which she considers to represent only "protective gear, outside of which her identity could be swayed, up for grabs" (Nguyen 2009, 16). Linny refuses to learn or speak Vietnamese, denies her cultural roots, and avoids the Vietnamese American community. She is afraid of confronting Vietnamese culture and history and her parents' past-knowledge of which she prefers to remain ignorant. Despite her successful assimilation into American popular culture, Linny feels insecure about her identity. In order to make herself more confident and visible, "Linny depended on high heels. Without them she felt diminutivea step away from being a little girl or a doddering old Asian woman"

3 I borrow the term psychospacial from Gaston Bachelard, The Poetics of Space: The Classic Look at How We Experience Intimate Places (Boston: Beacon, 1989) 7. 
(Nguyen 2009, 156). She does not want to have her name or identity attached to the manicure and pedicure business, mostly owned by Vietnamese Americans, so she shuns all nail salons as often as she can.

Concerning clothing and identity in American culture, Mary E. Roach-Higgins and Joanne B. Eicher argue that one's dress-which includes one's physical appearance, clothing, jewelry, and make-up-acts as a medium of non-verbal communication, and they reveal one's identity and relate to one's concept of the self. In this sense, "an individual's identities communicated by dress, bodily aspects of appearance, and discourse, as well as the material and social objects [. . .] contribute meaning to situations for interaction." Roach-Higgins and Eicher make the point that an individual can possess many identities, which both connect and separate him or her from others (Roach-Higgins et al, 1995, 12). Nguyen presents some of Linny's multi-identities as follows: "One day Linny was a Vietnamese girl with a jade bracelet, the next day she was trying on clothes at the mall, standing on tiptoes to try to match her tall blond friends" (Nguyen 2009, 170). Linny relies on clothing and adornment to create alternative identities for herself because she does not want to be stereotyped as just another Vietnamese manicurist. She believes that her investment in fashion will define the American identity that she aspires to assume, which will allow her to participate comfortably and seamlessly in social relations with non-Asian friends and lovers.

One's identity is defined when other people acknowledge that person as a social object, referring to him or her by employing the same words of identity that the person intends to hear (Stone 1995, 23-24). Thus, Linny's assumption or adoption of an American identity allows her to "join with some and depart from others, to enter and leave social relations at once" (Nguyen 2009, 23-24). Her sister and mother remark, for instance, that Linny does not date Asian men; in fact, she alienates herself from the Vietnamese community in Michigan by interacting exclusively with white and black American men. Madan Sarup, in her psychoanalysis of human identity, explains that, on the one hand, an individual wants to be "different from all other" people due to one's perception of one's own particularity. On the other hand, an individual wants to be "recognized, in one's unique particularity itself, as a positive value" within a local community, and one wants this recognition to be displayed publicly. Sarup uses the term universality to refer to the "social aspect of man's existence," and she states that "[i]t is only in and by the universal recognition of human particularity that individuality realizes and manifests itself" (Sarup 1993, 19-20). Mr. Luong, Linny, and Van are all subject to the manifestations of these dimensions of particularity and universality. Unlike her younger sister, Van, in order to make herself visible in American public spheres, always presents herself as an indus- 
trious, well-read, and ambitious overachiever. Root states that, ironically, while Asian American women's petiteness and shortness are seen as "physically attractive," these bodily features equate them with "diminished power and childlikeness" (Root 1998, 219). This certainly is the view long held by Mr. Luong.

Power and maturity, according to Van and her father, come from one's knowledge and accomplishments. In her childhood, she gained recognition among other American students in the classroom by volunteering to answer challenging questions, demonstrating top-quality academic performance, and eventually earning various scholarships at prestigious universities. According to Eleanor Ty, an Asian Canadian critic, "The markings on our [Asian] body have provoked from the dominant culture an array of responses that are predictable and overdetermined. Our Asian appearance continues to play a large role in determining how others read our identities, and its shapes, in ways both tangible and intangible" (Ty 2004, 8). Ty's insight provides a lens through which to view Van's perception of herself as a Vietnamese American. Van seems to have been influenced by her father's reminder that short people, as many Vietnamese tend to be, have to present themselves as smarter to prove their equality among the tall Americans. In order to escape cultural invisibility and be accepted visibly by American society, and to integrate herself successfully into American culture, Van has chosen the educational venue, suggested by her father as a way to develop her visible existence in the United States. It would seem, therefore, that Van has chosen substance over image, even as her sister Linny has chosen the alternative.

Although Van accomplishes her ambitious academic goals, her husband Miles once told her, "There's a core of insecurity about you," which she attributes to her limited height and her "being Asian in a mostly white, conservative town in the Midwest [. . .]. She had been standing on her tiptoes for most of her life" (Nguyen 2009, 111, 183). Due to her insecure feelings, she occasionally had to masquerade as a Caucasian to create an artificial comfort zone for herself. For example, when she was a student, she worked at the university fund-drive office, where she excelled among the other employees, partly because she masked her ethnic identity by referring to herself as "Vanessa" during telephone transactions. The people who talked to her "would never know who she was. They couldn't see her; they couldn't perceive her race, height, or anything about her. She relished being a disembodied voice" (Nguyen 2009, 184). Her retirement into a self-imposed, private invisibility illustrates Asian Americans' struggles to become visible in American society.

Whether Kandace Chuh is correct that Asian American writing should make political assertion or not, Asian American literature does, in 
general, address politics and political issues because the works present the voices of the minorities, the oppressed, and the "excluded others." In U.S. history, ethnic communities have experienced both random and governmental acts of racism and prejudice perpetuated by the predominantly white American public, and their predominantly white U.S. government. For this reason, Asian American literary texts and criticism, according to Gary Y. Okihiro, often aim at preserving and advancing "the principles and ideals of democracy" that make the United States a "freer place for all" (Okihiro 2002, ix), and the academic space that now is made available for the study of ethnic cultures is "the result of a long struggle for civil rights," just as Rey Chow concludes in Writing Diaspora (Chow 1993, 139). Short Girls, however, is a novel of domestic realism, and the characters' individualized perceptions of themselves in American culture are not determined so much by external racial prejudice as by internal aspirations and abilities, and the characters' personal struggle to realize them. Many mainstream Americans face such problems, also, and their dreams fail in their realization. The Vietnam War is over; the Vietnamese American community is establishing itself, and a new generation of Vietnamese Americans is dealing with frustrations that prevail throughout the society, but still under identifiably Vietnamese American circumstances.

Nguyen seems to imply that Vietnamese Americans should not be stereotyped as overachievers, geeks, math and science experts, or computer nerds. The Vietnamese Americans are just like everybody else in terms of personal ambitions, pursuits, and goals in life. By portraying her characters with contrasting values, personalities, and perspectives, Nguyen effectively demystifies the "model minority" image that prevails in American ethnic mythology, and which too often is perpetuated in Asian American writing. Her novel both stereotypes and de-stereotypes the main characters at the same time, in order to showcase the diversity in Vietnamese American community: not all Vietnamese American girls/ women are industrious, shy, and obedient; not all Vietnamese American men are passive, feminine, and asexual. ${ }^{4}$ Nguyen's novel takes Vietnamese American literature in a new direction by focusing its themes and characterizations upon post- rather than pre-assimilation situations. Effectively, the novel moves Vietnamese American literature into new, and potentially very fruitful, thematic areas.

\section{Conclusion}

In his 1992 study entitled The Vietnamese Experience in America, Paul James Rutledge notes that the Vietnamese Americans attempt to

4 Mr. Luong actually has an extramarital affair with Rich Bao's wife in the novel. 
maintain their traditional cultural heritage and participate in American popular culture at the same time. This process is neither acculturation nor assimilation (Rutledge 1992, 145-46). Similarly, in her 1995 book, The Viet Nam War/The American War, Renny Christopher observes that bifurcated sensibility, cultural negotiation, and biculturality are dominant themes in Vietnamese American literature. It is biculturality that differentiates Vietnamese American literature from the mainstream of Asian American literature, and "Vietnamese exile authors, while becoming 'American,' insist on remaining Vietnamese at the same time" (Christopher 1995, 30). Rutledge's and Christopher's observations seem no longer to be valid for many Vietnamese American novels published since 2003. The characters in Strom's Grass Roof, Tin Roof and in Nguyen's Short Girls do not negotiate their identities; the second-generation Vietnamese Americans in these two novels are not affected by their parents' pasts or memories.

It should be noted that, while earlier Vietnamese American authors, such as Lan Cao and le thi diem thuy, rely heavily on their family stories to construct their semi-autobiographical narratives, Truong, Strom, and Nguyen avoid this traditional storytelling approach. Their approach portends greater creativity in plot construction and in thematic development for Vietnamese American fiction. Another aspect to be noted is this: while homosexuality remains an uncommon topic in Vietnamese American literature, Truong chooses it as a main focus of her novel, and this is important, especially as racialization, queer diasporas, third-world homosexuality, and Asian American sexuality are becoming key issues in today's literary criticism.

In This Is All I Choose to Tell, the first book dedicated to the critical study of Vietnamese American literature, Isabelle Thuy Pelaud, in agreement with Thomas A. Dubois, states the Vietnamese American 1.5 generation is misrepresented and misunderstood if U.S. popular culture and readers keep associating the Vietnamese Americans with the Vietnam War and their pathetic refugee experiences. Pelaud concludes, "To view Vietnamese American texts only as refugee narratives restricts the full recognition of Vietnamese American experiences and identities" (Pelaud 2011, 59). The three Vietnamese American novels discussed here clearly indicate that a new generation of Vietnamese American writers can apply their considerable literary skills in ways unfettered by the political and cultural constraints that both stimulated and limited subjects and treatments found in earlier texts. These recent novels point forward an era of greater freedom in artistic expression for Vietnamese Americans who choose to articulate their perceptions in writing, even as they pursue their professional or vocational careers in a broad spectrum of fields. The Vietnamese American authors no longer are defined by or limited to one 
moment in Vietnamese or Vietnamese-exile experience. They have many new and significant avenues of experience to examine, and Truong, Strom, and Nguyen prove that Vietnamese American writers are examining them in innovative ways.

\section{NOTES}

\section{BIBLIOGRAPHY}

Barth, John. "The Literature of Exhaustion." Postmodern Literary Theory. Ed. Niall Lucy. Oxford, UK: Blackwell, 2000. 310-21.

Bates, Milton J. The Wars We Took to Vietnam: Cultural Conflicts and Storytelling. Berkeley, CA: U of California P, 1996.

"The Book of Salt: A Reader's Guide." http://www.houghtonmifflinbooks.com/readers_guides/truong_salt.shtml

Chae, Youngsuk. Politicizing Asian American Literature. Ed. Franklin Ng. New York: Routledge, 2008.

Chow, Rey. Writing Diaspora. Bloomington: Indiana UP, 1993.

Christopher, Renny. The Vietnam War, the American War: Images and Representations in Euro-American and Vietnamese Exile Narratives. Amherst: U of Massachusetts P, 1995.

Chuh, Kandice. Imagine Otherwise on Asian American Critique. Durham, NC: Duke UP, 2003.

Cohler, Deborah. "Teaching Transnationally: Queer Studies and Imperialist Legacies in Monique Truong's The Book of Salt." Radical Teacher 82: 25-31.

Danico, Mary Yu, and Franklin Ng. Asian American Issues. Westport, CT: Greenwood, 2004.

Damousi, Joy, and Mariano B. Plotkin. The Transnational Unconscious. New York: Palgrave Macmillan, 2009.

Eng, David L. Racial Castration. Durham, NC: Duke UP, 2001.

Fredrickson, George M. "Models of American Ethnic Relations: Hierarchy, Assimilation, and Pluralism." Doing Race. Ed. Hazel Rose Markus and Paula M. L. Moya. New York: Norton, 2010. 123-35.

Fung, Richard. "Looking for My Penis." Asian American Sexualities. Ed. Russell Leong. New York: Routledge, 1996. 181-98.

Ghost Bishnupriya, and Brinda Bose. "Introduction: Feminist Interventions and Locational Politics." Interventions: Feminist Dialogues on Third World Women's Literature and Film. New York: Garland, 1997. xv-xxxii. 
Glausen, Jan. “The Cook's Tale.” The Women's Review of Books 20.1011 (July 2003): 23.

Grice, Helena. Negotiating Identities: An Introduction to Asian American Women's Writing. Manchester, UK: Manchester UP, 2002.

Halberstam, Judith. "Boys will be . . . Bois? Or, Transgender Feminism and Forgetful Fish." Intersections between Feminist and Queer Theory. Ed. Diane Richardson, et al. New York: Palgrave, 2006. 97-115.

Kennedy, John F. "Remarks of Senator John F. Kennedy at the Conference on Vietnam Luncheon in the Hotel Willard, Washington, D.C., June 1, 1956." John F. Kennedy Presidential Library \& Museum. Historical Resources. <http://www.jfklibrary.org/Historical+Resources/ Archives/Reference $\ddagger$ esk/Speeches/JFK/JFK+Pre-Pres/1956/002PRE PRES12SPEECHES_56JUN01.htm>.

Kingston, Maxine Hong. The Woman Warrior. New York: Vintage, 1989. Print.

Koshy, Susan. "The Fiction of Asian American Literature." The Yale Journal of Criticism 9 (1996): 315-46.

Narayan, Uma. Dislocating Culture: Identities, Traditions, and ThirdWorld Feminism. New York: Routledge, 1997.

Nguyen, Bich Minh. Short Girls. New York: Viking, 2009.

Nguyen, Viet Thanh. Race and Resistance: Literature and Politics in Asian America. New York: Oxford UP, 2002.

Okihiro, Gary Y. Margins and Mainstreams: Asians in American History and Culture. Seattle: U of Washington P, 2002.

Pelaud, Isabelle Thuy. This Is All I Choose to Tell: History and Hybridity in Vietnamese American Literature. Philadelphia: Temple UP, 2011.

Pisares, Elizabeth H. "Payback Time: Neocolonial Discourses in Peter Bacho's Cebu." MELUS 29.1 (Spring 2004): 79-97.

Roach-Higgins, Mary Ellen, and Joanne B. Eicher. "Dress and Identity." Dress and Identity. Ed. Mary Ellen Roach-Higgins, Joanne B. Eicher, and Kim K. P. Johnson. New York: Fairchild, 1995. 7-18.

Root, Maria P. P. "Women." Handbook of Asian American Psychology. Ed. Lee C. Lee and Nolan W. S. Zane. Thousand Oaks, CA: SAGE, 1998. 211-31.

Rutledge, Paul James. The Vietnamese Experience in America. Bloomington: Indiana UP, 1992.

Sarup, Madan. An Introductory Guide to Post-structuralism and Postmodernism. Athens: U of Georgia P, 1993. 
Stone, Gregory P. "Appearance and the Self." Dress and Identity. Ed. Mary Ellen Roach-Higgins, Joanne B. Eicher, and Kim K. P. Johnson. New York: Fairchild, 1995. 19-39.

Strom, Dao. Grass Roof, Tin Roof. Boston: Houghton Mifflin, 2003.

Tolkas, Alice B. The Alice B. Tolkas Cook Book. New York: Harper and Brothers, 1954.

Truong, Monique. The Book of Salt. Boston: Houghton Mifflin, 2003.

Ty, Eleanor. The Politics of the Visible in Asian North American Narratives. Toronto: U of Toronto P, 2004.

$\mathrm{Xu}$, Wenying. Eating Identities: Reading Food in Asian American Literature. Honolulu: U of Hawaii P, 2007. 